Brit. J. vener. Dis. (1956), 32, 47.

\title{
EXTRACT FROM THE ANNUAL REPORT OF THE CHIEF MEDICAL OFFICER FOR THE YEAR 1954*
}

\section{VENEREAL DISEASES}

Syphilis.-In 1954 the number of new patients suffering from syphilis who attended the clinics in England and Wales fell to a record low level. As in previous years, this fall was most marked in the early infectious cases of less than one year's duration, though in a few clinics the numbers of primary and secondary cases have shown a slight rise.

Let us hope that the trend will continue and that it will signify a real diminution in the amount of infection in the country.

EARLY SYPHILITIC INFECTIONS DEALT WITH FOR THE FIRST TIME IN 1953 AND 1954 IN TEN SAMPLE URBAN AREAS

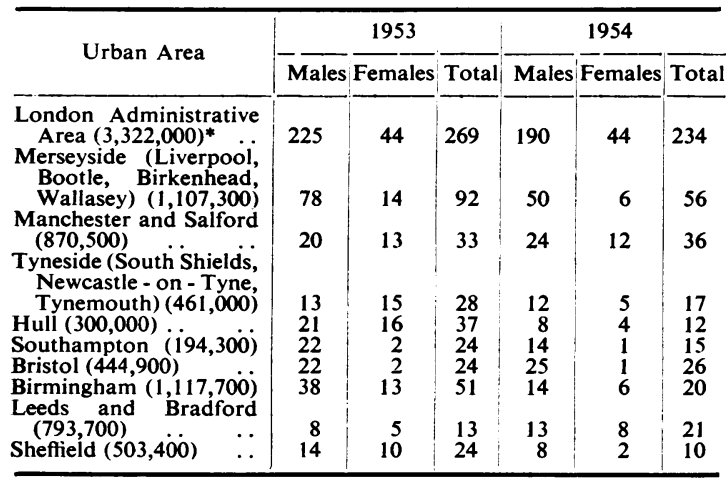

* The figures in brackets are the estimated population at 30 June, 1954.

The ratio of female to male patients treated continues to be fairly satisfactory (see Appendix, Tables A and B, p. 50). It will be seen from the following table that, though new cases of neuro-syphilis and what may be called late " benign" syphilis have fallen, those with cardio-vascular disease have increased, in spite of the fact that so many of these patients are treated elsewhere than in venereal diseases clinics. As syphilitic heart disease usually declares itself not less than fifteen years after infection and often much later, the melancholy harvest of fatal syphilis among the untreated cases of the second World War and the years immediately following has yet to appear. Routine blood testing

* Part II of the Report of the Ministry of Health for the year ended 31st December, 1954. Cmd. 9627, p. 63 and Appendix C. p. 233. of as many as possible of those who have been exposed to possible infection in the past may yet bring some of these patients under treatment before it is too late.

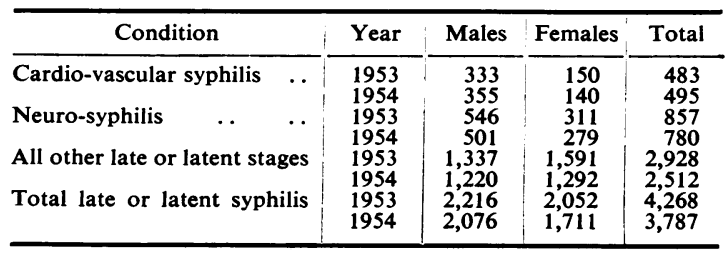

The persisting decrease in the numbers of late syphilitics attending the clinics may to some extent be due to the fact that, during the years of high prevalence, penicillin became increasingly available and consequently a far higher proportion of patients did in fact complete their treatment. A final judgement on the efficacy of this treatment cannot yet be given and will ultimately depend on the Registrar General's figures of deaths due to the disease during the next two decades. Table $\mathrm{E}$ of Appendix shows the trend in the number of deaths certified as being due to general paralysis of the insane, tabes dorsalis and aneurysm of the aorta. To these must be added the incalculable number caused by syphilitic disease of the aortic valves, and by other conditions due to syphilis omitted from death certificates in order to spare the feelings of the relatives.

There has been a welcome steep fall in the number of new cases of infantile congenital syphilis (48 as against 95). It would seem that these completely preventable infections are well on the way to being prevented, and there are grounds for hoping that the infection is diminishing as well as yielding to treatment. The number of cases of congenital syphilis among older children and adults has also fallen from 749 to 638 , a notable tribute to the work of the ante-natal and venereal diseases clinics during and immediately after the war, when the prevalence of early infectious syphilis was very high. Nevertheless, many infected mothers and babies must have escaped treatment during those difficult years and it is still likely that not a few cases of interstitial keratitis, a common manifestation of syphilis in childhood and adolescence, may yet 
CASES OF SYPHILIS (ANTE-NATAL), 1954

\begin{tabular}{|c|c|c|c|c|c|c|c|c|c|c|c|c|}
\hline \multirow{3}{*}{\multicolumn{5}{|c|}{$\begin{array}{c}\text { Regional Blood Transfusion } \\
\text { Centre }\end{array}$}} & \multicolumn{3}{|c|}{ No. of Ante-natal Patients Tested } & \multicolumn{5}{|c|}{ Positive Syphilis Tests } \\
\hline & & & & & \multirow{2}{*}{ Primiparae } & \multirow{2}{*}{ Multiparae } & \multirow{2}{*}{$\begin{array}{l}\text { Parity not } \\
\text { known }\end{array}$} & \multicolumn{2}{|c|}{ Primiparae } & \multicolumn{2}{|c|}{ Multiparae } & \multirow{2}{*}{$\frac{\begin{array}{c}\text { Parity not } \\
\text { known }\end{array}}{\text { No. }}$} \\
\hline & & & & & & & & No. & Per cent. & No. & Per cent. & \\
\hline Leeds . . & $\cdots$ & $\cdots$ & $\cdots$ & $\cdots$ & 7,917 & 9,097 & 4,645 & 28 & $0 \cdot 35$ & 45 & 0.49 & 10 \\
\hline Sheffield & $\cdots$ & $\cdots$ & $\cdots$ & $\cdots$ & 9,519 & 7,744 & 一 & 14 & $0 \cdot 15$ & 21 & $0 \cdot 27$ & - \\
\hline Liverpool & $\cdots$ & $\cdots$ & $\cdots$ & $\cdots$ & 15,337 & 17,910 & - & 38 & $0 \cdot 25$ & 40 & $0 \cdot 22$ & - \\
\hline \multicolumn{3}{|c|}{ Plymouth (sub-centre) } & $\cdots$ & $\cdots$ & 1,674 & 1,772 & - & 4 & $0 \cdot 24$ & 15 & 0.85 & - \\
\hline Oxford & $\cdots$ & . & $\ldots$ & $\cdots$ & 1,360 & 1,726 & 243 & 3 & $0 \cdot 22$ & 4 & 0.23 & - \\
\hline Cambridge & $\cdots$ & $\cdots$ & $\cdots$ & $\cdots$ & 636 & 5,978 & 6,803 & 2 & $0 \cdot 31$ & 25 & 0.42 & 19 \\
\hline \multicolumn{4}{|c|}{ South London (July-December) } & $\cdots$ & 2,738 & 3,714 & - & 2 & 0.07 & 3 & 0.08 & - \\
\hline \multicolumn{2}{|c|}{ Total } & $\cdots$ & $\cdots$ & $\cdots$ & 39,181 & 47,941 & 11,691 & 91 & $0 \cdot 23$ & 153 & $0 \cdot 32$ & 29 \\
\hline
\end{tabular}

occur. In passing, it may be mentioned that topical cortisone has greatly improved the prognosis of this serious ocular complication. (See Appendix, Table C, p. 50).

The number of pregnant women treated for syphilitic infection continues to increase. This is all to the good because every expectant mother found to be infected with syphilis and brought under immediate treatment means one less congenitally syphilitic child.

\section{Syphilis Testing in Pregnancy}

For the third successive year some of the Regional Blood Transfusion Centres have supplied information of the results of syphilis tests on blood samples submitted for routine examination during pregnancy for rhesus group and syphilis. The above Table shows the results for 1954 from the same six centres as previously, with the addition of the South London centre for the last six months of the year.

Except in Leeds, it is not known how many mothers had been tested previously and were being re-tested during a pregnancy in 1954. For Leeds the figures in the table refer to " new cases". In addition, 2,557 " old cases" were re-tested ; 2,302 of them were multiparae, with 11 positive results, i.e., 0.48 per cent.; in the remaining 255 parity was not known and there was one positive result.

The following table summarizes the results for the past three years :

\begin{tabular}{c|c|c|c|c}
\hline & $\begin{array}{c}\text { No. of } \\
\text { Primiparae }\end{array}$ & $\begin{array}{c}\text { Percentage } \\
\text { Positive }\end{array}$ & $\begin{array}{c}\text { No. of } \\
\text { Multiparae }\end{array}$ & $\begin{array}{c}\text { Percentage } \\
\text { Positive }\end{array}$ \\
\hline 1952 & 6,331 & 0.25 & 5,955 & 0.60 \\
\hline 1953 & 28,263 & 0.21 & 27,573 & 0.43 \\
\hline 1954 & 39,181 & 0.25 & 47,941 & 0.32 \\
\hline
\end{tabular}

All the figures refer to positive tests, and not necessarily to fully proved cases of syphilis.
Gonorrhoea.-The increase in the clinic incidence of gonorrhoea that took place during the last two years has not continued in 1954 and the number of patients of both sexes attending the clinics has fallen. It is possible that more patients are being treated privately than formerly, but no evidence on this point is available. The treatment of this disease in its early uncomplicated stages is now simple and fairly certain, and it is only when it is neglected, as it too frequently is in women, that serious complications are apt to occur.

Other Venereal Diseases.-Three hundred and one cases of chancroid in men and eight in women were seen during 1954 as against 347 and nine in 1953. Though many of the cases occur among visiting seamen, it is a feature of this disease that overt signs of infection are rarely seen in women. Sixty-three cases of lymphogranuloma venereum (Nicolas-Favre) were seen as against 76 in 1953. This disease occurs mainly in the tropics and it is possible that more cases may come to light among the increasing number of immigrants from overseas. Nine cases of the rare tropical venereal disease, granuloma inguinale (Donovan) were also reported.

New cases of non-gonococcal urethritis in men again rose from 13,157 in 1953 to 13,279 in 1954 and it will be seen that these numbers now approach those of gonorrhoea. This condition responds capriciously to various schemes of treatment, relapse frequently occurs and chronic longstanding cases, occasionally with stricture formation, are not uncommon. A small proportion develop acute or subacute arthritis and the possible relationship between non-specific urethritis and certain types of arthritis is being studied. Increasing numbers of the female consorts of these patients are being investigated and the number of women attending the clinics with " other conditions needing treatment" has risen from 9,834 to 10,117 . Most 
of these patients complain of vaginal discharge.

Non-specific urethritis continues to baffle the venereologists. Its cause is unknown and there is as yet no satisfactory treatment. As its social consequences may be quite as serious as those associated with gonorrhoea, Dr. G. L. M. McElligott, the Ministry's adviser strongly advocates that fundamental research into its cause be undertaken and persevered with.

Other Conditions treated at the Clinics.-The total number of patients with various other conditions needing treatment, many with a quasi-venereal background, is virtually unchanged at 23,188 . A further 34,154 were investigated and found to require no treatment.

Social Aspects.-Large numbers of male immigrants from overseas continue to attend the clinics in London and in one large clinic no less than 1,500 out of a total of 3,999 new male cases were not natives of the United Kingdom. As many of these men are homeless this is perhaps inevitable, but re-infection among them is common and their numbers are an indication of the extent to which strangers are responsible for the spread of venereal disease in London. On the other hand, the " reservoirs " of infection are situated among a large group of sexually promiscuous women, most of whom are unaware of their infectious state. Sooner or later not a few of these women find themselves in prison and in Holloway women's prison many of the inmates accept the offer of examination by a woman specialist. In this prison alone 61 cases of syphilis, 235 of gonorrhoea and 484 of other genital conditions needing treatment were discovered and treated during 1954. None of these patients had been treated previously, but 59 women, who had been treated in hospital clinics before admission to prison, were also examined as well as an additional 468 prisoners who had been examined during a previous stay in prison.
Of 256 known prostitutes examined during the year in Holloway, 36 were found to be suffering from syphilis, 102 from gonorrhoea and 76 from genital discharges from which the gonococcus was not isolated. Though urged to do so, comparatively few women seem to attend the hospital clinics for observation and tests of cure immediately after their release from prison. This neglect is understandable and is doubtless due to a natural reluctance to divulge the fact to anyone that they have been in prison. Not a few ex-prisoners do, however, attend the hospital clinics on some future occasion when they fear they may have been re-infected, so that the original introduction to a particular clinic on release from prison may not be altogether wasted.

Present Position.- - Though for the time being the spread of syphilis appears to be under control, the same cannot be said of gonorrhoea or of nongonococcal urethritis in men. It is possible, however, that the number of individuals affected continues to fall, as since the advent of penicillin, re-infection with gonorrhoea, particularly in men, has become relatively common. On the other hand, non-gonococcal urethritis is particularly prone to relapse and in this condition it is often impossible to distinguish relapses from re-infections.

Longstanding chronic gonorrhoea in women is notoriously difficult to diagnose and it sometimes happens that bacteriological evidence of infection is not readily found, even in the consorts of men known to be suffering from the disease. It is hard and often impossible to convince some women that an immediate diagnosis cannot always be made and it is often difficult to persuade them to return to the clinic for further tests. It is a moot point whether such contacts as are known to be promiscuous and seem unlikely to submit to repeated examination, should not be offered "insurance" treatment on epidemiological grounds at their first visit. 


\section{APPENDIX}

TABLE A

NUMBER OF CASES (IN ALL STAGES) DEALT WITH FOR THE FIRST TIME AT ANY CENTRE*

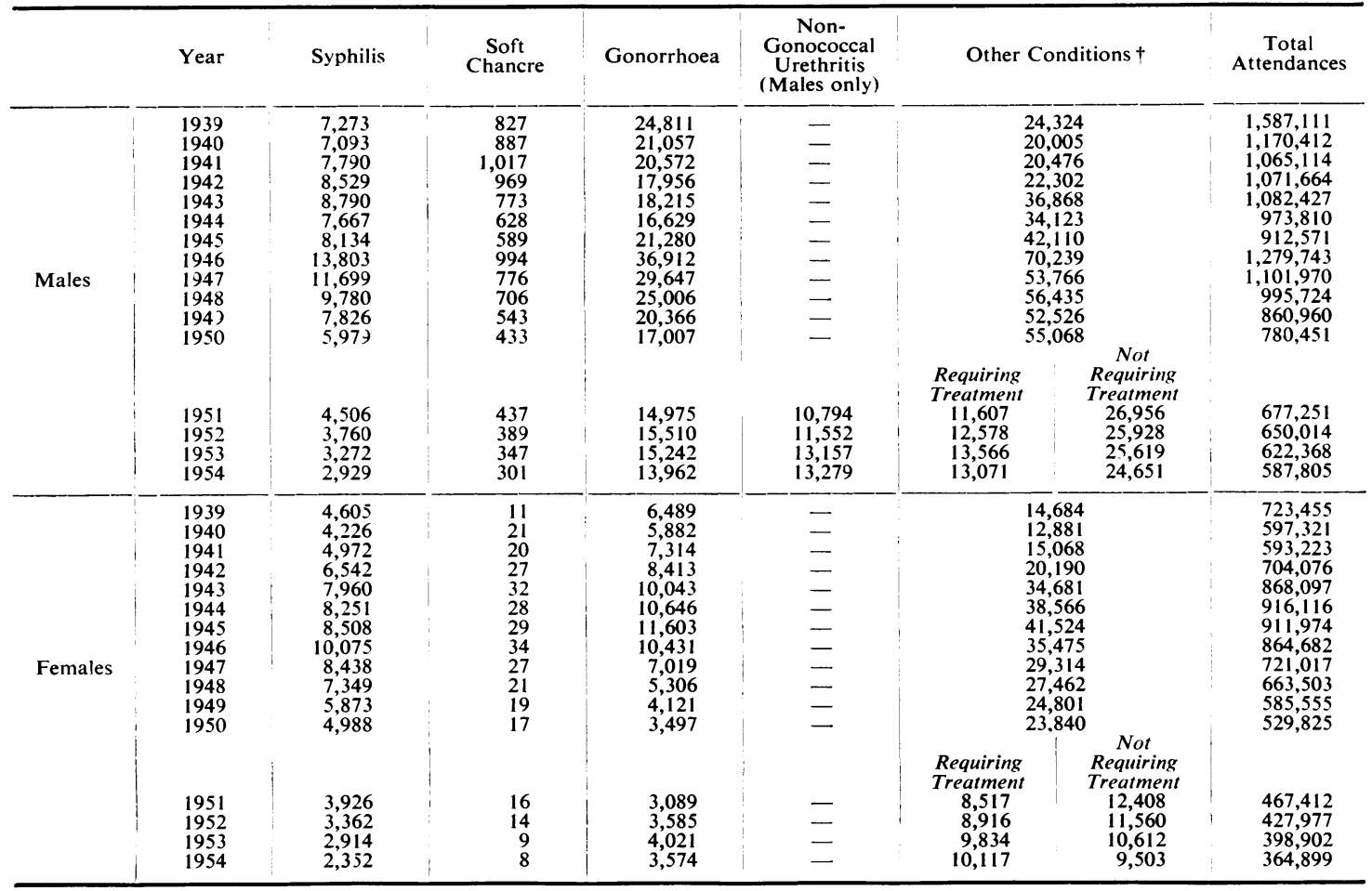

* Excludes cases transferred from centre to centre. † Including non-gonococcal urethritis up to 1950.

TABLE B

CASES OF ACQUIRED SYPHILIS IN TABLE A, WITH INFECTIONS OF LESS THAN ONE YEAR

\begin{tabular}{|c|c|c|c|c|}
\hline \multirow{2}{*}{ Year } & \multicolumn{2}{|c|}{ Number } & \multicolumn{2}{|c|}{ Per cent. of Table A Cases } \\
\hline & Males & Females & Males & Females \\
\hline 1931 & 6,421 & 2,683 & 56.9 & $39 \cdot 3$ \\
\hline 1932 & 6,196 & 2,532 & $56 \cdot 2$ & $39 \cdot 2$ \\
\hline 1933 & 5,949 & 2,141 & 55.4 & $35 \cdot 5$ \\
\hline 1934 & 4,888 & 2,030 & $50 \cdot 8$ & $3 \cdot 8$ \\
\hline 1935 & 4,226 & 1,745 & $49 \cdot 2$ & 31.4 \\
\hline 1936 & 4,033 & 1,642 & $49 \cdot 0$ & $32 \cdot 0$ \\
\hline 1937 & 3,986 & 1,647 & $49 \cdot 4$ & 31.9 \\
\hline 1938 & 3,744 & 1,494 & $47 \cdot 8$ & $30 \cdot 0$ \\
\hline 1939 & 3,574 & 1,412 & $49 \cdot 1$ & $30 \cdot 7$ \\
\hline 1940 & 4,029 & 1,582 & 56.8 & $37 \cdot 4$ \\
\hline 1941 & 5,023 & 2,309 & $64 \cdot 5$ & 46.4 \\
\hline 1942 & 5,470 & 3,576 & $64 \cdot 1$ & $54 \cdot 7$ \\
\hline 1943 & 5,159 & 4,483 & $58 \cdot 7$ & $56 \cdot 3$ \\
\hline 1944 & 4,384 & 4,934 & $57 \cdot 2$ & 59.8 \\
\hline 1945 & 5,214 & 5,527 & $64 \cdot 1$ & 64.9 \\
\hline 1946 & 10,705 & 6,970 & 77.6 & $67 \cdot 2$ \\
\hline 1947 & 8,750 & 5,416 & $74 \cdot 8$ & $64 \cdot 2$ \\
\hline 1948 & 6,603 & 4,034 & $67 \cdot 5$ & $54 . \overline{9}$ \\
\hline 1949 & 4,372 & 2,420 & $56 \cdot 1$ & $41 \cdot 2$ \\
\hline 1950 & 2,678 & 1,465 & $44 \cdot 8$ & 29.4 \\
\hline 1951 & $1,4) 8$ & 774 & $33 \cdot 2$ & $19 \cdot 7$ \\
\hline 1952 & 831 & 462 & $23 \cdot 7$ & 13.7 \\
\hline 1953 & 755 & 317 & 23.0 & 10.9 \\
\hline 1954 & 600 & 208 & $20 \cdot 5$ & 8.9 \\
\hline
\end{tabular}

TABLE C

CASES OF CONGENITAL SYPHILIS DEALT WITH FOR THE FIRST TIME AT THE TREATMENT CENTRES

\begin{tabular}{|c|c|c|c|c|c|}
\hline Year & $\begin{array}{l}\text { Under } \\
1 \text { Year }\end{array}$ & $\begin{array}{c}1 \text { and } \\
\text { under } \\
5 \text { Years }\end{array}$ & $\begin{array}{l}5 \text { and } \\
\text { under } \\
15 \text { Years }\end{array}$ & $\begin{array}{l}15 \text { Years } \\
\text { and over }\end{array}$ & Totals \\
\hline $\begin{array}{l}1931 \\
1932 \\
1933 \\
1934 \\
1935 \\
1936 \\
1937 \\
1938 \\
1939 \\
1940 \\
1941 \\
1942 \\
1943 \\
1944 \\
1945 \\
1946 \\
1947 \\
1948 \\
1947 \\
1950 \\
1951 \\
1952 \\
1953 \\
1954\end{array}$ & $\begin{array}{r}339 \\
302 \\
305 \\
296 \\
251 \\
241 \\
211 \\
216 \\
217 \\
191 \\
223 \\
245 \\
310 \\
346 \\
326 \\
363 \\
343 \\
372 \\
355 \\
227 \\
156 \\
110 \\
95 \\
48\end{array}$ & $\begin{array}{r}204 \\
180 \\
157 \\
165 \\
165 \\
132 \\
144 \\
123 \\
125 \\
101 \\
90 \\
122 \\
129 \\
113 \\
83 \\
103 \\
120 \\
142 \\
118 \\
141 \\
89 \\
101 \\
77 \\
41\end{array}$ & $\begin{array}{l}974 \\
857 \\
774 \\
708 \\
671 \\
600 \\
534 \\
448 \\
406 \\
357 \\
321 \\
309 \\
348 \\
271 \\
210 \\
215 \\
214 \\
215 \\
197 \\
203 \\
198 \\
191 \\
152 \\
119\end{array}$ & $\begin{array}{l}922 \\
805 \\
780 \\
839 \\
944 \\
935 \\
940 \\
951 \\
866 \\
709 \\
746 \\
788 \\
940 \\
822 \\
736 \\
701 \\
676 \\
678 \\
747 \\
652 \\
684 \\
547 \\
520 \\
478\end{array}$ & $\begin{array}{r}2,439 \\
2,144 \\
2,016 \\
2,008 \\
2,031 \\
1,908 \\
1,829 \\
1,738 \\
1,614 \\
1,358 \\
1,380 \\
1,464 \\
1,727 \\
1,552 \\
1,355 \\
1,382 \\
1,353 \\
1,407 \\
1,417 \\
1,223 \\
1,127 \\
949 \\
844 \\
686\end{array}$ \\
\hline
\end{tabular}


TABLE D

DEATH RATES PER 1,000 LIVE BIRTHS, OF INFANTS UNDER 1 YEAR CERTIFIED AS DUE TO CONGENITAL SYPHILIS

\begin{tabular}{|c|c|c|c|c|c|c|c|c|c|}
\hline \multicolumn{2}{|c|}{ Year } & Rate & Year & & Rate & Year & Rate & Year & Rate \\
\hline $\begin{array}{l}1912 \\
1913 \\
1914 \\
1915 \\
1916 \\
1917 \\
1918 \\
1919 \\
1920 \\
1921 \\
1922 \\
1923\end{array}$ & $\begin{array}{l}\ldots \\
\ldots \\
\ldots \\
\ldots \\
\ldots \\
\ldots \\
\ldots \\
\ldots \\
\ldots \\
\ldots\end{array}$ & $\begin{array}{l}1.34 \\
1.46 \\
1.55 \\
1.44 \\
1.57 \\
2.03 \\
1.90 \\
1.76 \\
1.51 \\
1.43 \\
1.12 \\
1.05\end{array}$ & $\begin{array}{l}1924 \\
1925 \\
1926 \\
1927 \\
1928 \\
1929 \\
1930 \\
1931 \\
1932 \\
1933 \\
1934 \\
1935\end{array}$ & $\begin{array}{l}\ldots \\
\ldots \\
\cdots \\
\cdots \\
\cdots \\
\cdots \\
\cdots \\
\cdots \\
\cdots\end{array}$ & $\begin{array}{l}0.91 \\
0.82 \\
0.84 \\
0.77 \\
0.71 \\
0.64 \\
0.55 \\
0.45 \\
0.42 \\
0.35 \\
0.30 \\
0.26\end{array}$ & $\begin{array}{l}1936 . \\
1937 \\
1938 \\
1939 \\
1940 \\
1941 \\
1942 \\
1943 \\
1943 \\
1944 \\
1945 \\
1946 \\
1947\end{array}$ & $\begin{array}{l}0.24 \\
0.19 \\
0.18 \\
0.17 \\
0.16 \\
0.21 \\
0.19 \\
0.23 \\
0.16 \\
0.15 \\
0.15 \\
0.09\end{array}$ & $\begin{array}{l}1948 \ldots \\
1949^{\circ} \ldots \\
1950^{*} \ldots \\
1951^{*} \ldots \\
1952^{*} \ldots \\
1953^{*} \ldots \\
1954^{*} \ldots\end{array}$ & $\begin{array}{l}0.09 \\
0.08 \\
0.04 \\
0.03 \\
0.03 \\
0.01 \\
0.03\end{array}$ \\
\hline
\end{tabular}

Rates for years 1931-1949 are according to the 1940 classification (5th Revision). For 1912-1930 the rates need to be multiplied by the

conversion ratio $0 \cdot 857$ for approximate comparability.
* For 1950-1954, No. $020 \cdot 2$ in International List (6th Revision).
TABLE E

DEATHS FROM GENERAL PARALYSIS OF THE INSANE, TABES DORSALIS, AND ANEURYSM OF THE AORTA

\begin{tabular}{|c|c|c|c|c|c|c|}
\hline \multirow{2}{*}{ Year } & \multicolumn{2}{|c|}{$\begin{array}{l}\text { General Paralysis } \\
\text { of the Insane }\end{array}$} & \multirow{2}{*}{$\begin{array}{c}\text { Tabes } \\
\text { Males }\end{array}$} & \multirow{2}{*}{ 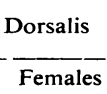 } & \multicolumn{2}{|c|}{$\begin{array}{c}\text { Aneurysm } \\
\text { Aorta }^{*}\end{array}$} \\
\hline & Males & Females & & & Males & Females \\
\hline $\begin{array}{l}1911-20 \ldots \\
1921-30 \ldots \\
1931-35 \ldots \\
1936-39 .\end{array}$ & $\begin{array}{r}1,697 \\
1,204 \\
819 \\
625\end{array}$ & $\begin{array}{l}383 \\
277 \\
240 \\
227\end{array}$ & $\begin{array}{c}592 \\
631 \\
566 \\
471\end{array}$ & $\begin{array}{l}106 \\
127 \\
125 \\
106\end{array}$ & $\begin{array}{r}838 \\
860 \\
969 \\
1,017\end{array}$ & $\begin{array}{l}208 \\
249 \\
393 \\
531\end{array}$ \\
\hline $\begin{array}{ll}1940-44 \ldots \\
1945-49 . . \\
1947 & \ldots \\
1948 & \ldots \\
1949 & \ldots \\
1950 & . \\
1951 & . \\
1952 & \ldots \\
1953 & \ldots \\
1954 & .\end{array}$ & $\begin{array}{c}482 \\
258 \\
283 \\
205 \\
161 \\
111 \\
121 \\
78 \\
91 \\
89\end{array}$ & $\begin{array}{r}167 \\
101 \\
116 \\
66 \\
65 \\
56 \\
47 \\
45 \\
26 \\
37\end{array}$ & $\begin{array}{r}270 \\
157 \\
164 \\
111 \\
114 \\
99 \\
111 \\
100 \\
87 \\
70\end{array}$ & $\begin{array}{l}71 \\
41 \\
44 \\
32 \\
20 \\
24 \\
32 \\
27 \\
26 \\
26\end{array}$ & $\begin{array}{l}467 \\
485 \\
502 \\
478 \\
515 \\
430 \\
475 \\
435 \\
408 \\
392\end{array}$ & $\begin{array}{l}158 \\
166 \\
177 \\
169 \\
191 \\
225 \\
204 \\
222 \\
190 \\
211\end{array}$ \\
\hline
\end{tabular}

The averages for the years 1911 to 1939 are based on the 4 th Revision of the International List. Figures for the years 1940 to 1954 are according to the 6th Revision.

Non-civilian deaths are excluded from the table from 3rd September, 1939, until 1949 for males, and from 1st June, 1941, until 1949 for females.

* For years 1911 to 1939 :-

"Aneurysm" (code 96) of the 4th Revision List, based on arbitrary rules of assignment.

For years 1940 and after :-

"Aneurysm of Aorta" (code 022) of the 6th Revision List, based on assignment by the certifying medical practitioner. Aortic Aneurysm specified as "non-syphilitic" or "dissecting" is no longer included in this heading. 